\title{
PERILAKU KEHIDUPAN KEAGAMAAN SANTRI DI PONDOK PESANTREN KARYA PEMBANGUNAN (PKP) MANADO
}

\author{
Nenden Herawaty Sulaiman \\ Institus Agama Islam Negeri (IAIN) Manado \\ herawaty.nenden@yahoo.com
}

\begin{abstract}
The existence of Islamic boarding schools in Indonesia has a big influence on the surrounding community. In terms of religious education, influence is not questionable. This is due to the establishment of Islamic boarding schools from the very beginning to educate and disseminate Islamic teachings to the community through recitation, both traditional and modern. The development of Islamic boarding school education in Indonesia is a manifestation of the community's need for an alternative and superior education system. This paper uses the Quantitative method with a field study at the Pondok Karya Permbangunan (PKP) boarding school, with the aim of getting more accurate data about the behavior of the religious life of the santri in the Manado Development Boarding School (PKP), to reveal the factors that influence the behavior of the religious life of the santri at the Manado Development Boarding School (PKP), to find strategies and efforts to resolve the obstacles faced in the behavior of religious life in the Manado Development Boarding School (PKP). Revitalizing Pesantren Spirit Ideas, Gait, and Reflection, by Muhammad M. Basyuni, generally divides into 3 (three) parts, namely in the first part explaining generally about Islamic education as a guardian to build national morals which are arranged in the second chapter concerning inner boarding schools. building a smart, religious and cultured generation and in the third chapter describes the centers of excellence, knitting traditions that are beginning to fade. Because it is very important to know for those who have concern for the presence of Islamic boarding schools, however, this research concerns the religious behavior of students specifically in Manado PKP.
\end{abstract}

Keywords: Religious Behavior, Santri, Pondok Karya Pembangunan.

Abstrak. Keberadaan pesantren di Indonesia berpengaruh besar terhadap masyarakat disekitarnya. Dalam hal pendidikan agama, pengaruh tidak perlu dipertanyakan lagi. Hal ini disebabkan dari sejak awal berdirinya pesantren disiapkan untuk mendidik dan menyebarkan ajaran-ajaran Islam kepada masyarakat melalui pengajian, baik dengan sistem tradisional maupun modern. ${ }^{1}$ Perkembangan pendidikan pondok pesantren di Indonesia merupakan perwujudan dari kebutuhan masyarakat akan suatu sistem pendidikan alternatif dan unggul. Tulisan ini menggunakan metode Kuantitatif dengan study lapangan di pesantren Pondok Karya Permbangunan (PKP) Manado, dengan tujuan Untuk mendapatkan data yang lebih akurat mengenai perilaku kehidupan keagamaan santri yang ada di pondok Pesantren Karya Pembangunan (PKP) Manado, Untuk mengungkapkan faktor-faktor yang mempengaruhi perilaku kehidupan keagamaan santri di pondok Pesantren Karya Pembangunan (PKP) Manado, Untuk menemukan strategi dan upaya penyelesaian terhadap kendala yang dihadapi dalam perilaku

1Wahjoetomo, Perguruan Tinggi Pesantren: Pendidikan Alternatif, (Jakarta: Gema Insani Press, 1997), h. 90 
kehidupan keagamaan di pondok Pesantren Karya Pembangunan (PKP) Manado. Revitalisasi Spirit Pesantren Gagasan, Kiprah, dan Refleksi, oleh Muhammad M. Basyuni, secara umum membagi ke dalam 3 (tiga) bagian, yakni pada bagian pertama menjelaskan secara umum tentang pendidikan Islam sebagai garda membangun moral bangsa yang dirangkai pada bab kedua menyangkut pesantren dalam membangun generasi cerdas, religius, dan berbudaya serta pada bab ketiga menguraikan pusat-pusat keunggulan, merajut tradisi yang mulai memudar. Karena itu sangat penting diketahui bagi yang memiliki kepedulian terhadap kehadiran pesantren, namun demikian penelitian ini menyangkut tentang perilaku keagamaan santri khusus di PKP Manado.

Keywords: Perilaku Keagamaan, Santri, Pondok Karya Pembangunan. 


\section{Pendahuluan}

Pelaksanaan ajaran Islam dalam kehidupan sehari-hari akan terwujud dengan baik dan berkesinambungan apabila nilai-nilai agama terstruktur dan terpelihara dalam kehidupan pribadi dan masyarakat yang berawal dari keluarga karena itu, pengaturan dan kesinambungan dalam kehidupan di tuntut oleh ajaran ajaran Islam. ${ }^{2}$

Keberadaan pesantren di Indonesia berpengaruh besar terhadap masyarakat disekitarnya. Dalam hal pendidikan agama, pengaruh tidak perlu dipertanyakan lagi. Hal ini disebabkan dari sejak awal berdirinya pesantren disiapkan untuk mendidik dan menyebarkan ajaran-ajaran Islam kepada masyarakat melalui pengajian, baik dengan sistem tradisional maupun modern. ${ }^{3}$

Perkembangan pendidikan pondok pesantren di Indonesia merupakan perwujudan dari kebutuhan masyarakat akan suatu sistem pendidikan alternatif dan unggul. Selain menyediakan jasa pendidikan yang sehat, lembaga pondok pesantren juga diharapkan memenuhi prinsip-prinsip keilmuan sesuai standar nasional.

Pesantren hampir tak pernah absen memberikan respon terhadap perubahan masyarakat, khususnya pada aspek pendidikan. Inovasi terhadap pesantren banyak dilakukan, baik oleh internal pengelola pesantren maupun pihak eksternal yang memberikan dukungan.

Diantara tata nilai yang berkembang di pesantren adalah bahwa seluruh aktifitas kehidupan adalah bernilai ibadah. Sejak memasuki lingkungan pesantren, seorang santri telah diperkenalkan dengan suatu model

2Lihat, M. Quraisy Syihab, Membumikan Al Qur'an, (Bandung: Mizan, 1992), h. 257

3Wahjoetomo, Perguruan Tinggi Pesantren : Pendidikan Alternatif, (Jakarta: Gema Insani Press, 1997), h. 90 kehidupan yang bersifat keibadatan. Dengan demikian, ketaatan seorang santri terhadap Kyai, misalnya, merupakan manifestasi atas ketaatan yang dipandang sebagai ibadah. ${ }^{4}$

Di sisi lain, perhatian pemerintah (Departemen Agama RI) terhadap keberadaan lembaga pendidikan pesantren, menurut Maftuh Basyuni kurang mendapat perhatian. Menurutnya 91.8\% berupa lembaga pendidikan swasta, berupa madrasah dan pesantren selama ini tak pernah terjangkau oleh uluran tangan pemerintah, ditambahkan bahwa, lima puluh delapan tahun, madrasah dan pesantren Ngak kopenan (terus) oleh pemerintah. Akibatnya, pesantren yang Kyainya kreatif, bisa maju, tapi yang Kyainya pasrah, lillahi ta'ala, pesantrennya la yamutu wa la yahya (mati enggan, hidup pun segan). ${ }^{5}$

Hal ini menarik untuk dikaji, sebab di satu sisi pesantren sebagai lembaga pendidikan yang telah mapan dan berhasil di dalam mengaktualisasikan nilai-nilai ajaran Islam dalam kehidupan sehari-hari sehingga menjadi kebanggaan bagi umat Islam, sementara di sisi lain mampukah santri PKP Manado mengintegrasikan nilai-nilai ajaran agama Islam dalam perilaku kehidupan keagamaan seharihari khususnya dalam lingkungan PKP Manado.

\section{Lembaga Pendidikan Islam}

Secara umum, lembaga pendidikan dalam Islam dibagi ke dalam 3 (tiga) bagian yakni lembaga pendidikan formal, informal, dan non formal, ketiga lembaga pendidikan dalam Islam tersebut, maka lembaga pendidikan informallah yang pertama kali bersentuhan dalam lingkungan keluarga (rumah tangga).

${ }^{4}$ Ibid., h. 97

${ }^{5}$ Muhammad M. Basyuni, Revitalisasi Spirit Pesantren, Gagasan, Kiprah, dan Refleksi, (Jakarta : Direktorat Pendidikan Diniyah dan Pondok Pesantren Dirjen Pendidikan Islam Dapag, 2007), h. 7 
Sebagai lembaga pendidikan informal dalam lingkungan keluarga, maka pendidikan agama Islam yanga. diberikan dalam rumah tangga sangat menentukan pembentukan karakter dan pendidikan anak itu sendiri.

Ayah dan ibu sebagai orangtua dan pendidik yang pertama-tama memiliki fungsi dan peran yang sangat menentukan dan bertindak sebagai guru bagi anakanaknya. Pendidikan dan pengajaran yang mula-mula harus diberikan oleh sang Ayah atau ibu adalah dengan memberikan pendidikan akhlak berupa cerita-cerita sejarah para Nabi, yang biasanya diberikan sebelum tidur atau pada waktuwaktu berkumpul serta menuntun praktek ibadah shalat dengan cara mengajak anak-anak untuk turut shalat berjamaah di rumah atau di sanggar/mesjid. ${ }^{6}$

Dalam lingkungan rumah tangga (keluarga) terjadi proses pendidikan yakni orangtua sebagai guru sedangkan anak-anak adalah murid. Proses pendidikan tersebut merupakan bentuk tanggung jawab orangtua terhadap anakanaknya di dalam mendidik, membimbing, dan mengasuh agar anak tersebut tidak salah arah (jalan), disamping itu merupakan amanah Allah swt., yang harus dilakukan oleh setiap orangtua terhadap anak-anaknya.

Allah swt., berfirman dalam QS. (66) At-Tahrim : 6 yang artinya, Hai orang-orang yang beriman, peliharalah dirimu dan keluargamu dari api neraka yang bahan bakarnya adalah manusia dan batu; penjaganya malaikat-malaikat yang kasar, keras, dan tidak mendurhakai Allah terhadap apa yang diperintahkan-Nyab. kepada mereka dan selalu mengerjakan apa yang diperintahkan. ${ }^{7}$

6Edy Sadyawati, et.al., Sejarah Pendidikan di Indonesia Sebelum Kedatangan Bangsa Barat, (Jakarta: Departemen P dan K, 1991), h. 48

${ }^{7}$ Departemen Agama RI, Al Qur'an dan Terjemahnya (Jakarta: Yayasan Penyelenggara Penterjemah/Pentafsir Al Qur'an, 2005), h. 310
Adapun lembaga pendidikan dalam Islam dapat dikategorikan sebagai berikut :

\section{Lembaga Pendidikan Pesantren}

Sebagai lembaga pendidikan Islam, maka pendidikan pesantren memegangperanan yang sangat penting dalam membina dan mendidik santri untuk dapat hidup mandiri kelak serta akan menjadi benteng terhadap kemajuan dan kejayaan agama Islam.

Menurut Edy Sedyawati dkk, bahwa :

Pesantren pada dasarnya adalah sebuah pendidikan Islam tradisional dimana para santrinya tinggal dan belajar bersama di bawah bimbingan seseorang atau lebih yang disebut Kiyai. Asrama untuk para santri tersebut berada dalam lingkungan kompleks pesantren dimana tempat untuk beribadah, ruang untuk belajar dan kegiatan-kegiatan lain. ${ }^{8}$

Bahkan di tambahkan bahwa :

Pada lembaga pendidikan pesantren, Kyai bersama-sama muridnya tinggal dalam satu pondok yang dinamai asrama. Sistem pendidikan seperti ini mirip dengan sistem pendidikan guru kula yaitu guru hidup bersama para santrinya. Tentunya tidak dapat dikatakan bahwa sistem pendidikan pesantren muncul sesuai dengan lajunya peradaban Islam.

Keberadaan kehidupan pesantren yakni kemampuan untuk berdiri atas kaki sendiri. Kemampuan hidup mandiri ini terlihat dari perkembangan pesantren dari masa ke masa. Dengan pola kehidupan yang unik, pesantren mampu bertahan barabad-abad untuk mempergunakan nilai-nilai hidupnya sendiri. Hal ini terlihat dari keberadaan pesantren sampai zaman sekarang ini. ${ }^{9}$

Lembaga Pendidikan Madrasah

Istilah Madrasah berasal dari bahasa Arab, dari kata darasa yang berarti tempat untuk belajar. Di Indonesia kata madrasah diartikan sebagai lembaga pendidikan

\footnotetext{
8Edy Sedyawati, (et.al), Sejarah Pendidikan di Indonesia Sebelum Kedatangan Bangsa Barat, (Jakarta: Departemen P\& K, 1991), h. 48 ${ }^{9}$ Ibid.
} 
Islam di bawah naungan Departemen Agama. Madrasah terdiri dari jenjang, yaitu madrasah Ibtidaiyah sederajat dengan Sekolah Dasar, madrasah Tsanawiyah sederajat dengan Sekolah Menengah Pertama, dan madrasah Aliyah sederajat dengan Sekolah Menengah Atas. 10

Kehadiran madrasah adalah merupakan tumpuan harapan masyarakat muslim Indonesia dalam rangka mencerdaskan kehidupan umat Islam. Hal mana merupakan salah satu bentuk alternatif dengan munculnya kegiatan pendidikan antara model pesantren di satu pihak dan model pendidikan umum.

Karenanya, dalam pendidikan madrasah siswa bukan hanya mendapatkan pengetahuan ilmu agama Islam, akan tetapi juga mendapatkan pengetahuan umum dengan porsi yang telah diatur dalam Keputusan Bersama 3 Menteri yaitu Menteri Agama, Menteri Pendidikan dan Kebudayaan, dan Menteri Dalam Negeri.

Kedudukan madrasah dalam sistem pendidikan nasional dapat dilihat dari Keputusan Bersama 3 Menteri yaitu : Menteri Agama, Menteri Pendidikan dan Kebudayaan, dan Menteri Dalam Negeri, Nomor 6 tahun 1975/U 1975, Nomor 36 tahun 1975 tentang peningkatan mutu pendidikan pada madrasah, Madrasah Ibtidaiyah setingkat dengan Sekolah Dasar, Madrasah Tsanawiyah setingkat dengan Sekolah Menengah Pertama, dan Madrasah Aliyah setingkat dengan Sekolah Menengah Atas. ${ }^{11}$

c. Lembaga Pendidikan Tinggi Islam

Lembaga pendidikan tinggi Islam merupakan lembaga pendidikan tertinggi dari semua lembaga pendidikan Islam yang diharapkan akan menghasilkan sarjana muslim yang memiliki kemampuan dan keterampilan dalam

${ }^{10}$ Badri Yatim, Sejarah Peradaban Islam, (Cet. III; Jakarta: Raja Grafindo Persada, 1993), h. 203

11Ibid., h. 5 mengkaji ajaran agama Islam secara mendalam, komprehensif, ilmiah, dan penuh tanggung jawab.

Lembaga pendidikan tinggi Islam merupakan kelanjutan dari lembaga pendidikan sebelumnya, yakni lembaga pendidikan tingkat Atas (Madrasah Aliyah, SMU maupun yang sederajat).

Pada saat sekarang, lembaga pendidikan tinggi Islam yang berkembang di Indonesia yang berstatus negeri adalah Universitas Islam Negeri (UIN), Institut Agama Islam Negeri (IAIN), maupun Sekolah Tinggi Agama Islam Negeri (STAIN). Sementara lembaga pendidikan tinggi Islam yang berstatus swasta jauh lebih banyak dibandingkan dengan negeri.

Dengan demikian, maka lembaga pendidikan Islam yang ada di Indonesia, mulai dari pesantren, madrasah maupun pendidikan tinggi Islam menjadi tanggung jawab umat Islam pada umumnya dalam rangka peningkatan mutu dan kualitasnya, dan terlebih lagi perhatian pihak pemerintah sangat diharapkan agar lembaga pendidikan Islam tersebut tetap eksis.

Untuk lebih memantapkan keberadaan lembaga pendidikan Islam, sekaligus melaksanakan Undang-Undang Nomor 20 Tahun 2003 tentang sistem Pendidikan Nasional, maka pemerintah telah mengeluarkan ketentuan dalam bentuk Peraturan Pemerintah RI Nomor 55 Tahun 2007 tentang Pendidikan Agama dan Pendidikan Keagamaan.

Dalam pasal 8 ayat 1 PP Nomor 55 Tahun 2007 disebutkan bahwa pendidikan keagamaan berfungsi mempersiapkan peserta didik menjadi anggota masyarakat yang memahami dan mengamalkan nilai-nilai ajaran agamanya dan/atau menjadi ahli agama.

Bahkan dalam pasal 9 ayat $2 \mathrm{~h}$ PP Nomor 55 Tahun 2007 disebutkan bahwa pendidikan keagamaan diselenggarakan pada jalur pendidikan formal, nonformal, dan informal. Hal ini berarti bahwa pemerintah bukan hanya mengakui 
keberadaaan lembaga pendidikan formal, akan tetapi juga telah mengakui keberadaan dari setiap lembaga pendidikan nonformal maupun informal.

\section{Sistem Pendidikan Pesantren}

Sistem pendidikan yang dianut suatu pesantren pada awal berdirinya tidaklah menganut sistem klasikal. Pada umumnya sistem penjenjangan pendidikan melalui kitab-kitab yang dikaji.

Tujuan pendidikan yang ingin dicapai di pondok pesantren pada umumnya mengutamakan program pendidikan kader ulama yakni mempersiapkan calon kader ulama di masa yang akan datang dengan berbekal penguasaan ilmu pengetahuan agama yang mendalam sehingga mampu mengamalkannya dalam kehidupan sehari-hari dalam pesantren serta memiliki kepekaan dan kepedulian terhadap kelangsungan agama Islam.

Karena itu, pada awalnya setiap santri yang mondok dipesantren diberikan pelajaran kitab matan, yaitu kitab yang belum berisi kitab syarah dan setelah santri telah mampu menguasai kitab matan tersebut, kemudian dilanjutkan dengan mengkaji kitab-kitab syarah. Oleh karena itu dalam sitem ini tidak direncanakan kapan seorang santri dapat menyelesaikan pendidikan atau dianggap tidak mampu. Seorang santri dapat disebut berhasil apabila dia telah mendapat persetujuan dari Kiainya untuk mengajarkan ilmu ke orang lain. Sistem pendidikan seperti ini banyak didapati di Jazirah Arab, yang disebut dengan pendidikan halaqah.

Halaqah berasal dari bahasa Arab yang berarti lingkaran. Halaqah adalah metode pendidikan bagi pengajaran secara kolektif. Para santri dalam menerima pelajaran kuliah duduk melingkar mengelilingi kiainya yang sedang memberikan pelajaran. Para santri juga aktif menyimak dan memberikan catatan-catatan di kitab yang sedang dipelajarinya. Di Jawa istilah halaqah disebut dengan weton, sedangkan di Jawab Barat disebut dengan bandungan. ${ }^{12}$

Pada zaman Walisongo, pondok pesantren memainkan peran penting dalam penyebaran agama Islam di pulau Jawa. Juga pada zaman penjajahan Belanda, hampir semua peperangan melawan pemerintah kolonial Belanda bersumber atau paling tidak dapat dukungan sepenuhnya dari pesantren. ${ }^{13}$

Pesantren pada umumnya memiliki kesamaan antar satu pesantren dengan pesantren yang lain yakni adanya kesamaan ideologi serta memiliki kesamaan referensi dengan metode pengajaran dan pemahaman yang sama, sehingga membuat pesantren memiliki kekuatan yang cukup signifikan dapat diperhitungkan oleh siapapun juga.

Adapun jenjang pendidikan yang diselenggarakan oleh lembaga pendidikan pesantren diatur dalam pasal 26 ayat $2 \mathrm{~h}$ PP Nomor 55 Tahun 2007 yang menyebutkan : Pesantren menyelenggarakan pendidikan diniyah atau secara terpadu dengan jenis pendidikan lainnya pada jenjang pendidikan anak usia dini, pendidikan dasar, menengah, atau pendidikan tinggi.

Sementara itu, terkait dengan uji kompetisi bagi peserta didik dipesantren diatur dalam pasal 26 ayat $3 \mathrm{~h}$ PP Nomor 55 Tahun 2007 yang meyebutkan :

Peserta didik/atau pendidik di pesentren yang diakui keahliannya dibidang ilmu agama tetapi tidak memiliki ijazah pendidikan formal dapat menjadi pendidik mata pelajaran/kuliah menempuh ujian kompetensi sesuai ketentuan perundang-undangan.

\section{${ }^{12}$ Lihat Tim Penulis IAIN Syarif}

Hidayatullah, Ensiklopedi Islam Indonesia, (Jakarta: Djambatan, 1992), h. 290-291

${ }^{13}$ Hasbullah, Sejarah Pendidikan Islam di Indonesia: Lintasan Sejarah Pertumbuhan dan Perkembangan, (Jakarta: PT Raja Grafindo Persada, 1999), h. 149 
Dimensi kegiatan sistem pendidikan yang dilaksanakan oleh pondok pesantren bermuara pada suatu sasaran utama yakni adanya perubahan, baik secara individual maupun kolektif. Oleh karena itu pondok pesantren sebagai agen perubahan, yang berarti pesantren sebagai lembaga pendidikan agama yang mampu melakukan perubahan terhadap masyarakat.

Secara umum ada tiga pola sikap pesantren menghadapi arus modernisme; pertama, menolak secara total. Sikap ini dibuktikan dengan menutup diri secara total terhadap medernisme, baik pola pikir maupun sistem pendidikan dengan cara menjaga otentisitas tradisi dan nilai pesantren secara ketat, baik dalam bentuk symbol maupun substansi. Pesantrenpesantren tidak memasukkan pelajaran umum dan tetap menggunakan pola bandongan, sorongan dan wetonan dalam metode pendidikannya. Mereka juga menolak penerapan formalisme pesantren sebagaimana tercermin dalam SKB tiga Menteri.

Kedua, menerima modernisme secara total baik pemikiran, model maupun referensinya. Disini tidak sengaja diajarkan nilai-nilai agama dengan referensi kitab klasik, tetapi juga diajarkan pengetahuan umum. Kurikulum yang digunakan juga kurikulum umum, tidak lagi kurikulum pesantren yang menggunakan kitab mu'tabar.

Ketiga, ini yang mayoritas, menerima modernisme secara selektif. Pada pola ini ada proses kreatif dari kalangan pesantren dalam menerima modernisme, yaitu menerima sebagian modernisme kemudian dipadu dengan tradisi pesantren. Pada pola ini pesantren menerapkn metode-metode modern dalam sistem pengajaran, memasukan referensi-referensi pengetahuan umum dalam pendidikan, namun kitab-kitab klasik dengan pola pengajaran ala pesantren tetap diterapkan. ${ }^{14}$

Menurut Hasan Basri bahwa dalam realitas menunjukkan pada saat ini lembaga pesantren telah berkembang secara bervariasi dengan mengelompokkan ke dalam lima pola yaitu :

a. Pesantren yang hanya terdiri dari mesjid dan rumah Kyai,

b. Pesantren yang hanya terdiri dari mesjid, rumah Kyai, dan asrama

c. Pesantren yang hanya terdiri dari mesjid dan rumah Kyai, asrama dan madrasah.

d. Pesantren yang terdiri dari mesjid dan rumah Kyai, asrama, madrasah, dan latihan keterampilan

e. Pesantren yang terdiri dari mesjid dan rumah Kyai, asrama, tempat keterampilan, universitas, gedung pertemuan, tempat olahraga, dan sekolah umum. ${ }^{15}$

Dengan demikiansistem pendidikan pada pesantren terdiri dari beberapa unsur yang saling terkait dalam rangka mewujudkan apa yang dicitacitakan.

Dengan demikian, sistem pendidikan pesantren harus mampu mengaplikasikan produk tekhnologi modern, hal ini dikarenakan keberadaan pesantren sampai sekarang telah menjadi kebanggaan tersendiri bagi umat Islam di tengah-tengah arus globalisasi, individualis, dan pola hidup materialistik yang semakin menunjukkan keberadaannya.

Disamping itu pesantren harus mampu dan konsisten mempertahankan kitab kuning sebagai salah satu elemen dasar dari tradisi pesantren.

\footnotetext{
${ }^{14}$ Lihat Ngatawi El-Zastrow, Sebuah Transformasi Dunia Pesantren, Jurnal Pondok Pesantren Mihrab, (Jakarta: Ed.I Tahun IV, Dep. Pendidikan Diniyah dan Pondok Pesantren Depag RI, 2006), h. 5-6

${ }^{15}$ Hasan Basri, Pesantren dan Pendidikan Keagamaan, (Jakarta: Pustaka, 1989), h. 45
} 


\section{Kesimpulan}

ecara umum ada tiga pola sikap pesantren menghadapi arus modernisme; pertama, menolak secara total. Sikap ini dibuktikan dengan menutup diri secara total terhadap medernisme, baik pola pikir maupun sistem pendidikan dengan cara menjaga otentisitas tradisi dan nilai pesantren secara ketat, baik dalam bentuk symbol maupun substansi. Pesantrenpesantren tidak memasukkan pelajaran umum dan tetap menggunakan pola bandongan, sorongan dan wetonan dalam metode pendidikannya. Mereka juga menolak penerapan formalisme pesantren sebagaimana tercermin dalam SKB tiga Menteri.

Kedua, menerima modernisme secara total baik pemikiran, model maupun referensinya. Disini tidak sengaja diajarkan nilai-nilai agama dengan referensi kitab klasik, tetapi juga diajarkan pengetahuan umum. Kurikulum yang digunakan juga kurikulum umum, tidak lagi kurikulum pesantren yang menggunakan kitab mu'tabar.

Ketiga, ini yang mayoritas, menerima modernisme secara selektif. Pada pola ini ada proses kreatif dari kalangan pesantren dalam menerima modernisme, yaitu menerima sebagian modernisme kemudian dipadu dengan tradisi pesantren. Pada pola ini pesantren menerapkn metode-metode modern dalam sistem pengajaran, memasukan referensi-referensi pengetahuan umum dalam pendidikan, namun kitab-kitab klasik dengan pola pengajaran ala pesantren tetap diterapkan.

\section{DAFTAR PUSTAKA}

Basyuni Muhammad M., Revitalisasi Spirit Pesantren, Gagasan, Kiprah, dan Refleksi, Jakarta : Direktorat Pendidikan Diniyah dan Pondok Pesantren Dirjen Pendidikan Islam Dapag, 2007
Dardjat Zakiah, Ilmu Pendidikan Islam, Jakarta: Bumi Aksara, 1992

Departemen Agama RI, Al Qur'an dan Terjemahnya Jakarta: Yayasan Penyelenggara/ Penterjemah Al Qur'an, 1983

Dhofier Zamakhsyari,Tradisi Pesantren: Studi Tentang Pandangan Hidup Kiyai, Jakarta: LP3ES, 1982

El-ZastrowNgatawi, Sebuah Transformasi Dunia Pesantren, Jurnal Pondok Pesantren Mihrab, Jakarta: Ed.I Tahun IV, Dep. Pendidikan Diniyah dan Pondok Pesantren Depag RI, 2006

Hasan Basri, Pesantren dan Pendidikan Keagamaan, Jakarta: Pustaka, 1989

Hasbullah, Sejarah Pendidikan Islam di Indonesia: Lintasan Sejarah Pertumbuhan dan Perkembangan, Jakarta: PT Raja Grafindo Persada, 1999

Ismail Arifuddin, Efektivitas Pendidikan Kader Ulama di Berbagai Pesantren, Jurnal Al-Qalam, Makassar: Balai Penelitian dan Pengembangan Agama Makassar, Nomor XVII Tahun XII, 2006

Madjid Nurchlish, Islam, Doktrin, dan Peradaban, Cet.; Jakarta: Yayasan Wakaf Paramadina, 1992

MarimbaAhmad D, Filsafat Pendidikan Islam Bandung: PT Al-Ma'arif, 1989

Mastuhu, Dinamika Sistem Pendidikan Pesantren, Jakarta: INIS, 1994

Sadali A, (et.el), Islam Untuk Disiplin Ilmu Pendidikan Jakarta: Bulan Bintang, 1989

SadyawatiEdy, et.al., Sejarah Pendidikan di Indonesia Sebelum Kedatangan Bangsa Barat, Jakarta: Departemen P dan K, 1991. 
Syihab M. Quraisy, Wawasan Al Qur'an, Cet. II; Bandung: Mizan, 1996.

Tim Penulis IAIN Syarif Hidayatullah, Ensiklopedi Islam Indonesia, Jakarta: Djambatan, 1992.

Wahjoetomo, Perguruan Tinggi Pesantren : Pendidikan Alternatif,Jakarta: Gema Insani Press, 1997.

Yatim Badri, Sejarah Peradaban Islam, Cet. III; Jakarta: Raja Grafindo Persada, 199 